\title{
HISTOCHEMICAL OBSERVATIONS ON THE LIPID CHANGES IN THE OVARIAN INTERSTITIAL GLAND TISSUE OF RATS
}

\author{
S. S. GURAYA \\ Department of Zoology, College of Basic Sciences and Humanities, \\ Punjab Agricultural University, Ludhiana, Punjab, India
}

(Received 3rd February 1975)

\begin{abstract}
Summary. Lipid changes were studied histochemically in the ovarian interstitial tissue of untreated and hormone-treated rats during the oestrous cycle, pseudopregnancy, pregnancy and lactation. The hormones tested were $\mathrm{LH}$, prolactin and oestradiol benzoate, alone or in combination. Conspicuous lipid changes occurred only in response to LH.
\end{abstract}

The lipid droplets of CL in normal untreated rats show conspicuous changes in their amount and histochemical composition during various reproductive states, and seem to be regulated by the changing levels of $\mathrm{LH}$ and prolactin (Guraya, 1975a, b). In order to determine the comparative response of CL and interstitial gland tissue to endogenous and exogenous hormones, a parallel histochemical study was also carried out on the lipid changes of the latter in intact and hormone-treated rats during different reproductive states, and these results are reported here.

The lipids were histochemically analysed in the ovarian interstitial tissue of intact and hormone-treated Holtzman rats during the oestrous cycle, pseudopregnancy, pregnancy and lactation. The rats, weighing 255 to $300 \mathrm{~g}$, were kept in an air-conditioned room with a controlled lighting regimen of $14 \mathrm{hr}$ light/10 hr dark. Vaginal smears were examined each morning and only rats with regular 4- or 5-day oestrous cycles were used. The day spermatozoa were found in the vaginal smear was designated Day 1 of pregnancy, and the day of parturition was designated Day 1 of lactation. Details of the histochemical methods and hormones used have been described in previous papers (Guraya, $1975 \mathrm{a}, \mathrm{b}$ ). Briefly, frozen sections of ovaries fixed in formaldehyde calcium and post-chromed in dichromate calcium were submitted to various histochemical tests for lipids, e.g. Sudan black B test for lipids, Nile blue sulphate and red Sudan dyes tests for neutral and acidic lipids, acid haematein test for phospholipids, and Schultz test for cholesterol and/or its esters (see Pearse, 1968). The details of the various experiments are shown in Tables 1 and 2.

The ovarian interstitial tissue, which is not noticeable in rat ovaries after routine histological treatment, showed accumulation of deeply sudanophilic lipid droplets during the oestrous cycle, pseudopregnancy, pregnancy and 
lactation, which consisted mainly of cholesterol and/or its esters, triglycerides and phospholipids (Table 1). Cholesterol-positive lipid droplets were invariably depleted from the tissue in ovaries examined just before ovulation (Table 1). The relatively low levels of lipids during metoestrus and on Days 1 and 2 of pseudopregnancy, pregnancy and lactation indicated that replenishment was occurring at these times when endogenous LH is high (Guraya, 1975a). Complete depletion of cholesterol-positive lipid droplets was not seen, possibly because new lipid droplets originated at the same time as mobilization. It is also possible that some involuting interstitial tissue did not release lipid droplets after gonadotrophic stimulation (Guraya, 1973).

Table 1. Summary of the lipid changes in the ovarian interstitial gland tissue during various reproductive states in the intact rat

\begin{tabular}{|c|c|c|c|c|}
\hline \multirow{2}{*}{ Reproductive state } & \multirow{2}{*}{$\begin{array}{l}\text { Accumulation of } \\
\text { lipid droplets }\end{array}$} & \multicolumn{3}{|c|}{ Composition of lipid droplets } \\
\hline & & Phospholipids & Triglycerides & $\begin{array}{l}\text { Cholesterol and/or } \\
\text { its esters }\end{array}$ \\
\hline $\left.\begin{array}{l}\text { Oestrous cycle } \\
\text { Metoestrus } \\
\text { Dioestrus } \\
\text { Pro-oestrus } \\
\text { Oestrus } \\
\text { Early metoestrus }\end{array}\right\}$ & $\begin{array}{l}\text { Moderate to heavy } \\
\text { Heavy } \\
\text { Sparse to moderate }\end{array}$ & $\begin{array}{l}+ \text { to }++ \\
+ \text { to }++ \\
+ \text { to }+++\end{array}$ & $\begin{array}{r}+ \text { to }+++ \\
++ \text { to }+++ \\
+ \text { to }+++\end{array}$ & $\begin{array}{c}+ \text { to }+++ \\
+++ \text { to }++++ \\
+ \text { to }++\end{array}$ \\
\hline $\begin{array}{l}\text { Pseudopregnancy } \\
\text { and pregnancy } \\
\text { Day } 1 \text { to } 2 \\
\text { Day } 3 \text { onwards }\end{array}$ & $\begin{array}{l}\text { Sparse to moderate } \\
\text { Moderate to heavy }\end{array}$ & $\begin{array}{l}+ \text { to }+++ \\
+ \text { to }++\end{array}$ & $\begin{array}{r}+ \text { to }+++ \\
++ \text { to }+++\end{array}$ & $\begin{array}{r}+ \text { to }++ \\
++ \text { to }++++ \\
\end{array}$ \\
\hline $\begin{array}{l}\text { Lactation } \\
\text { Day } 1 \text { to } 2 \\
\text { Day } 3 \text { onwards }\end{array}$ & $\begin{array}{l}\text { Sparse to moderate } \\
\text { Moderate to heavy }\end{array}$ & $\begin{array}{l}+ \text { to }+++ \\
+ \text { to }++\end{array}$ & $\begin{array}{l}+ \text { to }+++ \\
+ \text { to }+++\end{array}$ & $\begin{array}{c}+ \text { to }++ \\
++ \text { to }+++\end{array}$ \\
\hline
\end{tabular}

Key to abbreviations: $+=$ weak reaction; $++=$ moderate reaction; $+++=$ strong reaction; $++++=$ very strong reaction.

Only exogenous $\mathrm{LH}$ was effective in depleting the cholesterol-positive lipid droplets from interstitial tissue during the oestrous cycle, pregnancy and lactation (Table 2). Previous histochemical and biochemical data have demonstrated that LH stimulates steroidogenesis in interstitial tissue (Zarrow \& Clark, 1969; Armstrong et al., 1969; Guraya, 1973), but the exact mechanism of its action is still controversial. Treatment with prolactin neither increased nor decreased the high levels of cholesterol-positive lipid droplets in the interstitial tissue, a finding which supports the biochemical data of Armstrong et al. (1969), although Zarrow \& Clark (1969) reported that prolactin caused a cholesterol accumulation not only in the luteal compartment but also in the interstitial tissue. Their experiments, however, did not eliminate the possibility of stimulation of progesterone production in the rat CL by prolactin. It has been shown that $\mathrm{LH}$ and prolactin act synergistically to regulate the metabolism of cholesterol- and triglyceride-containing lipid droplets in the rat CL (Guraya, 1975b), but this does not seem to be true for the interstitial tissue which responds mainly to LH only. 


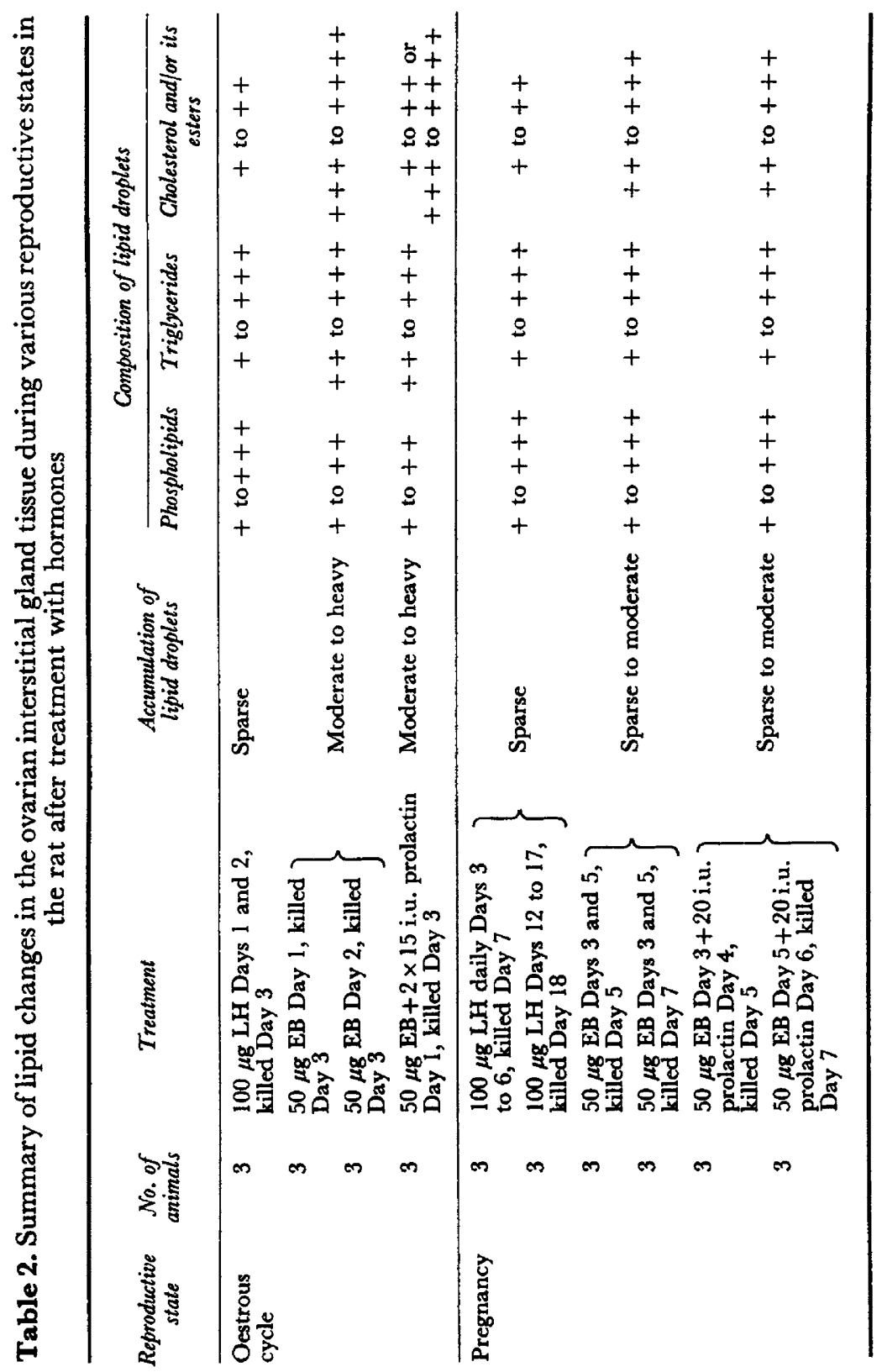




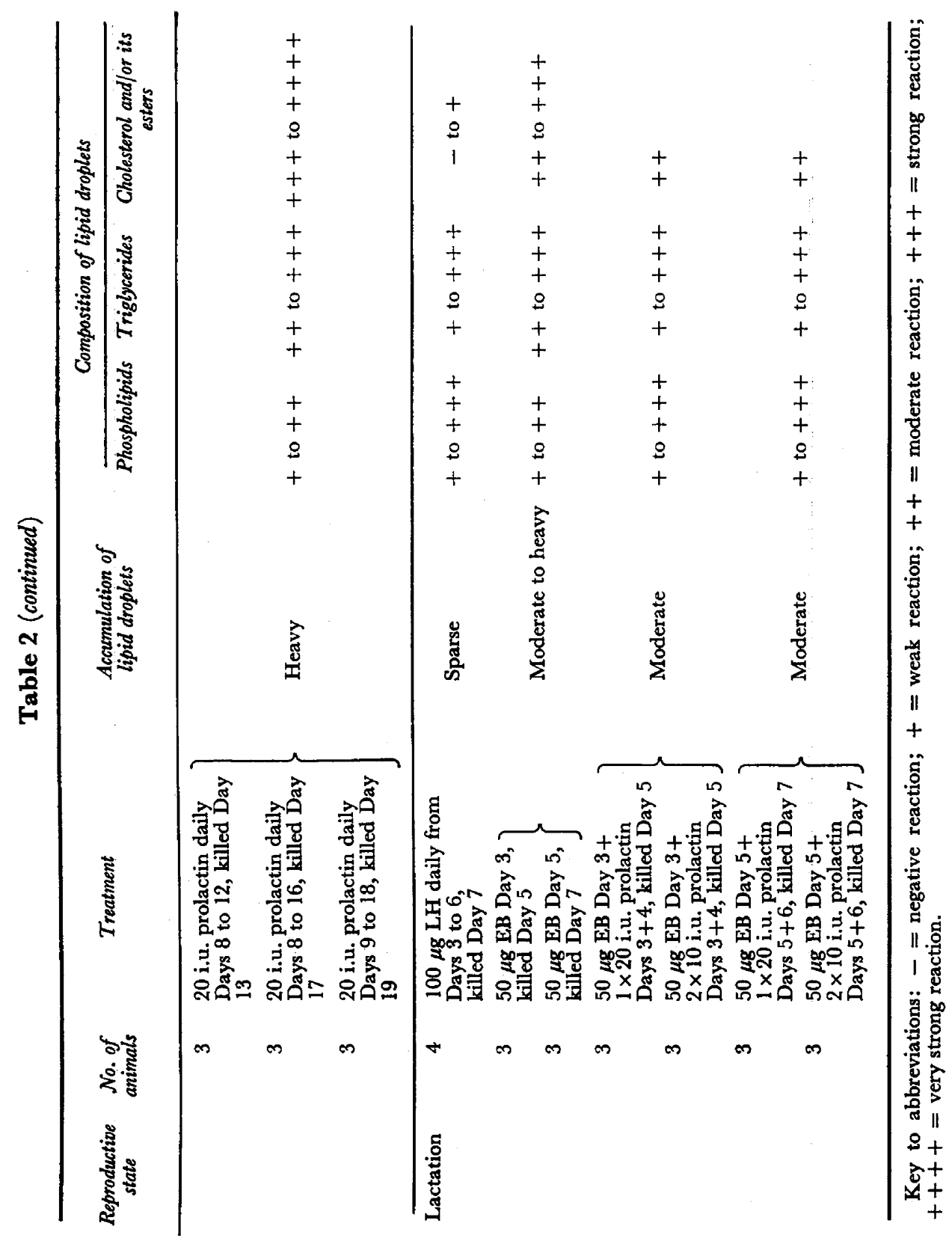


It is well established that the depletion of cholesterol-containing lipid droplets from the interstitial tissue of the rabbit ovary in response to both endogenous and exogenous LH is related to the production of progestins. A similar function of steroid production can perhaps be assigned to the depletion of cholesterol-containing lipid droplets from the interstitial tissue of the rat ovary after stimulation by LH.

\section{REFERENCES}

ARMstrong, D.T., MrLLER, L.S. \& KnUDSEN, K.A. (1969) Regulation of lipid metabolism and progesterone production in the rat corpora lutea and ovarian interstitial elements by prolactin and luteinizing hormone. Endocrinology 85, 393-401.

GuRaya, S.S. (1973) Interstitial gland tissue of mammalian ovary. Acta endocr., Copenh. 72, Suppl. $171,1-27$.

Guraya, S.S. (1975a) Histochemical observations on the lipid changes in rat corpus luteum during various reproductive states. 7. Reprod. Fert. 42, 59-65.

GURAYA, S.S. (1975b) Histochemical observations on the lipid changes in rat corpora lutea during various reproductive states after treatment with exogenous hormones. F. Reprod. Fert. 43, 67-75.

Pearse, A.G.E. (1968) Histochemistry. Churchill, London.

ZarRow, M.X. \& CLARK, J.H. (1969) Gonadotropin regulation of ovarian cholesterol levels in the rat. Endocrinology 84, 340-346. 